\title{
The Significance of Museums to Fine Art Education in Oman
}

\author{
Fakhriya Al-Yahyai \\ Art Education Department, Sultan Qaboos University, Muscat, Oman \\ Email: fakhriya@squ.edu.om
}

How to cite this paper: Al-Yahyai, F. (2017). The Significance of Museums to Fine Art Education in Oman. Art and Design Review, 5, 189-199.

https://doi.org/10.4236/adr.2017.53015

Received: July 22, 2017

Accepted: August 13, 2017

Published: August 16, 2017

Copyright $\odot 2017$ by author and Scientific Research Publishing Inc. This work is licensed under the Creative Commons Attribution International License (CC BY 4.0).

http://creativecommons.org/licenses/by/4.0/

\begin{abstract}
This article explores the importance of Fine Art Museums to Art Education in the context of Oman. Although it will shed light, other creative avenues of Art education have developed in the country, such as collaboration and small private exhibitions, and it is argued here that there can be no complete substitute for public Fine Art museums to help develop Artists' understanding and knowledge of their field. It will play a role in filling the gap of knowledge with regard to the function played by Museums with regard to Fine Art Education in Oman.
\end{abstract}

\section{Keywords}

Fine Art Education, Museums, Oman

\section{Introduction}

This research draws attention to the role of Art Museums as they act as cultural centers for students, professional Artists and the general public alike. Social and educational functions are considered an important purpose of art museums, such as service to the community, society, and public. Classroom learning is only one part of the development of an Artist's understanding of Fine Art. Fine Art Museums are places where students' understanding of the language of Art flourishes and where appreciation of the aesthetic, critical and historical value can be fully explored and understood. Museums play a fundamental role in Art Education. They are regarded as centers to promote critical thinking and imagination, which might not otherwise be explained or even explainable in a classroom. Museums create partnership with schools and provide learning resources no single school could hope to provide. It is proffered that Fine Art Museums educate the public in understanding and appreciating beauty and the aesthetic of life and that without such a resource the understanding of our surroundings is in- 
complete. The topic of the significance of Museums to Fine Art Education in general and in Oman in particular is a substantial topic. It is proposed that the development of a Fine Arts centre will contribute significantly not only to Art students in Oman but also to all students and the general public.

According to Al-Amri (2006) in Oman, the Ministry of Heritage and Culture realized from the beginning that museums are the most important means through which nations can preserve their prestigious heritage, history and their flourishing future. It is a window to enable present and future generations to have a glimpse of the achievements and great efforts of their fathers and ancestors. Therefore, in Oman, there are different kinds of museums such as: the National Museum, the Natural History Museum, the Omani-French Museum, the Child's Museum and the Military Museum. However, Al-Amri (2006) draws our attention to the issue of not having an art museums in Oman and he elaborates further that "the Omani government provides moral and financial support to the artists to exhibit their works both in Oman and in foreign countries around the globe but they do not have Art museums that display the works of masters in the their respective fields. In Oman, an Art museum does not exist yet and it therefore cannot play a role in teaching Art and consequently, Art teachers cannot integrate and benefit from such a great resource in their classroom instruction". Because of this, he concluded that "it is important that the Omani government understands the role of Art museums and galleries in teaching visual arts; Art museums can provide students with the opportunity to feel and experience firsthand the sublime power of great Art and the sense of beauty" (Al-Amri, 2006: 9).

As a result of Al-Amri's discussions and findings, there is a need to establish art and culture organizations such as art museums and galleries, in addition to what we have in Oman, to enhance the standard and profile of visual Art in Omani society. Therefore, this study, explores the significance of Museums of Fine Arts and their potentials in educating peoples about the values, beauty and aesthetics art education.

Education policies almost universally acknowledge the value of Visual and Fine Art; students flourish when creativity drives learning. What does Art Education do for society and the individual? According to the National Art Education Association, there are three important and distinct answers: "Beyond the qualities of creativities, self-expression and communication, art is a type of work. There is a desperate need in our society for a revival of the idea of good work: work for personal fulfillment; work for social recognition; work for economic development. Work is one of the noblest expressions of the human spirit, and art is the visible evidence of work carried to the highest possible level. Art is a language of visual images that everyone must learn to read. The individual who cannot understand or read images is incompletely educated. Complete literacy includes the ability to understand, respond to, and talk about visual images. Therefore, to carry out its total mission, art education stimulates language-spoken and written-about visual images. Art means values. Art can express the 
highest aspirations of the human spirit. Great art of the past and the present deals with these durable human concerns. Values shape all human efforts, and visual images can affect students' personal value choices" (National Art Association, 2015).

Shall we only value Art Education on the premise that it has social and economic benefits? Art Education develops the mind and the soul. As (Langer, 1967: 487) explains that "Viewing education as a useful social engineering mechanism has undermined its substantive and historic role". Langer also suggested in (Innis, 2008: 158) that "Art is the objectification of feeling, and in developing our intuition, teaching eye and ear to perceive expressive form, it makes form expressive for us wherever we confront it, in actuality as well as in art". The magnificence of art lies in its indeterminate character, which allows infinite possibilities of interpretation and expression. Fine Art does not discuss the question of "why does it exist?" Or "what is it for?" Stimulating the love of learning and teaching students the sense that there are other ranges of Art to investigate, these should be the fundamental and ultimate goal of Art Education.

Art Education prepares students for jobs and to be citizens. It teaches them to be human beings who can enjoy the deeper forms of beauty. This third element is as essential as the other two. Art Education can permeate in young people a sense of the values that allow civilised life to go on. Everyone should have a fervent experience of the arts both through their cultural history and their own practical experience.

\section{The Aim of the Study}

The aim of the current study is to highlight the significance of Museums to Fine Art Education in general and in Oman in particular. The study will highlight the most important areas of Fine Art Education, as follows:

-The need for Museums in Art education.

-Most important resources for education.

-Reliable sources of historical and objective information; Museums enable the public to think for themselves.

-Develop culture and heritage. Museums educate and serve every community.

-Alternative approach to the development of Art Education in Oman.

-The potential effects of Museums on Art Education in Oman.

\section{The Need for Museums in Art Education}

The definition of a museum has progress, in line with developments in society. According to International Council of Museums (ICOM, 2007) A museum is a non-profit, permanent institution in the service of society and its development, open to the public, which acquires, conserves, researches, communicates and exhibits the tangible and intangible heritage of humanity and its environment for the purposes of education, study and enjoyment. The statement is regarded as definitive across international communities. The theorist Hein (1998) stated in his book, learning in the Museum, that Museums provide an ideal learning 
environment, whether it is formal or informal learning, active, hand-on participation or passive observation.

Schools and individuals should have the opportunity to experience all that museums have to offer: permanent collections, special exhibitions, regular tours, introductions to the galleries, access to libraries, archives and study rooms, concerts, films, workshops such as life drawing sessions, curatorial talks and lectures from industry expert focusing on art, architecture, archeology, music and culture, Art history courses, social and drop-in events.

Across the world museums are state schools' leading educational partner. Via educational departments and school programs they should work together to ensure students attain cultural literacy. Museums do not just designate cultural identity, they provide it through framing and help to extend and enhance the delivery of the school curriculum. Cook (2007) believes that the heart of experiential learning is physical action, normally with hands touching materials. Through Museums, the abstract of the classroom becomes "real" with "concrete" artifacts, books and other materials. Students explore materials and how things are made. The educational philosopher (Dewey, 1933: 278) said that just as education is an "emancipating and enlargement experience", it also is always an "affair of action". This characteristic links the museum with the real world. Schools should be committed to introducing children to the best there is, in as many art forms as possible. Visits to Museums allow them to see real iconic objects from the past. The public can view original models of architecture. Students explore drawing, photography, posters, and typography; worlds of Art, Craft, Design, and performance that will go on to inspire them. Museums produce a range of resources for teachers to help elevate students' experience of the Museums. The educational departments can arrange "study days" to allow more extensive exploration of the cultural background to an exhibition or area of the collections. Also, online resources are usually robust. It is feasible to search the collection online, to download free images, and watch-inspiring videos of curators, historians and more. Museums can be viewed as an extension of schools with additional facilities and resources to aid teaching and facilitate the learning process.

\section{Reliable Sources of Historical and Objective Information}

As stated by Wallace, in (Anderson, 1991) the importance of Museums resides in their role as a nation's memory bank. He confirms that Museums are a source of "living history". The established way to envision the museum is as a sacred space. Museums present history to the public and are a reliable source of historical information for researchers, teachers and students alike. When we observe museum objects we contemplate something pure and "authentic"-unaltered since its creation. Objects possess an aura that provides spiritual enlightenment as it inspires Platonic values of beauty and morality. Indeed, museums artifacts are "authentic" masterpieces that reveal universal truths in an established canon or standard of excellence.

According to Marstine (2006) Museums in there essence are transparent in 
their decision-making, willing to share power, and activists in promoting human rights. It is a neutral environment of learning with objectivity. Marstine (2006) also explains that "Post-museum-an institution that declares itself an active player in the making of meaning". These "Post-Museums" provide more handson, interactive and touch-friendly activities as the public feel the need for constant entertainment. Museums are changing to engage a public that is desensitized to thinking for themselves. Fogg Art Museum curator Ivan Gaskell explains in (Marstine, 2006) that objects have an "afterlife" which must be acknowledged if we are to be critical thinkers. Indeed, museums guide viewers to assign meaning to objects totally unrelated to their original design, intention or function. Wall texts providing context and other educational materials are assigned to promote a one-on-one relationship between the audience and object. According to (McClellan, 2003: 26) the former Director of the National Gallery in London, Kenneth Clark, stated that "We do not value pictures as documents. We do not want to know about them; we want to know them, and explanations may too interfere with our direct responses." Therefore, Art Museums enable the public to think for themselves and make connections between stakeholders including normal people and professional educators such as teachers, artists and students. Museum will be always sources of artistic historical information that taking a place in any country and this rich source will remain with the next generation.

\section{Develop Culture and Heritage}

Museums educate and serve every community. They help communities to better understand and appreciate cultural diversity. They help us to appreciate the breadth of human accomplishments. Indeed, viewers discover the history, heritage the depth of culture. They see the creative side of nations, their strengths. Students discover world cultures, legacy of rulers, celebrate the lives and achievements of those who have influenced history, culture and identity through displays and exhibitions.

Researchers from the University of Arkansas, in partnership with Crystal Bridges Museum of American Art, have conducted the first large-scale randomized controlled trial demonstrating the benefits students receive from visiting an art museum as it clarified by Holtrop (2016) Students who visit museums are able to recall school visit themes at very high rates, demonstrate stronger critical thinking skills, display higher tolerance, exhibit greater historical empathy, and develop a taste for art museums and cultural institutions. Besides, disadvantaged students from rural schools, low-income and minority are the first beneficiaries of school visits to museums. These results indicate that art could be a major tool for effectively delivering traditional academic content. Hooper-Greenhill (2007: 2) also explains how learning transforms who we are and what we can do. She discusses, is just not an accumulation of skills and facts, but a process of becoming.

According to (Cook, 2007) the social relationships are another important element of experiential learning. Most of the time, visitors to museums come with 
friends or family. Even when alone, they may be affected socially by other visitors or museum personnel such as docents, curators, or guards. Dewey (1913/ 1970) found this relationship worthwhile, not only for children, who love approval and whose every action is bound up with others, but also for adults because they, too, like to engage with others. Hein (1998), a constructivist himself, encouraged more social interaction and networking for learning of all kinds in the museum. Stone (1996) also argues that art teachers where they in or pre-service should have an understanding of what it means to teach in art museum or in galleries and it is recommended that museums should be utilized as a resource for the art curriculum. Therefore, the Art educators at university setting need to develop students' understanding of their own heritage and culture in addition to other cultural heritages through museums surrounding the students' environment as well as through world-cultures (Al-Amri, Al-Radaideh, Al-Yahyai, Almamari, \& Alhajri, 2016).

In the context of developing Omani culture and heritage, it is important as (Al-Amri, 2001) argues that in today's context that the more the future generation becomes appreciative of its cultural heritages, the more chances there are that the heritage itself will remain with the future generation to preserve and enjoy for the future. Regarding the artistic cultural heritage in art, Gibson (2003) mentions that learners will understand and study different ways of experiences in order to develop a great representation and understanding of their cultural beliefs and values. As a result, learners will learn through art museum education to take risks, be imaginative, and explore alternative solutions of their won cultural heritages, and try to develop kind of engagement which might solve challenges of today's Omani culture and heritage inquiring for the next generations.

\section{Alternative Approach to Developing Art Education in Oman}

Art Museum Education can make a significant contribution to educate learners in Oman. Art Museum can be regarded as an alternative approach to developing Art Education in Oman, however, to date, Oman has a number of museums that display items of local heritage and history, such as the Natural History Museum, the Omani-French Museum, the Children's Museum and the Military Museum. These museums are all useful in promoting and educating those who wish to know about Oman's cultural heritage. However, these heritage centres cannot be used as substitutes for Fine Art Museums. To have a centre where Visual and Fine Art is displayed creates a teaching resource greater than any classroom or Art studio. Fine Art museums are places where beauty and aesthetic are celebrated and can teach more about the language of art than any classroom explanation.

In 2009, Al Salmi library in Oman broke new ground in the world of Fine Art by exhibiting at the Grand Hyatt hotel, Muscat 100 artworks of the world's most celebrated and highly regarded artists, Rembrandt van Rijn. The most famous artworks on display were shown for the first time in the Middle East. It is unfor- 
tunate, however, that such works had to be shown in a hotel, which itself had to be specially climate controlled for the duration of the exhibition due to the potential damage the countries humidity could have done to the works. It would be a great statement of Oman's cultural awareness and sensitivity to Visual and Fine Art to have a space which could house and display the works of world renown Masters alongside those of local Omani Artists. This would not only establish a cultural hub but also an environment in which local Art and Artists could thrive and would also help to provide an infinitely wider platform on which Omani Artists could stand on equal footing with the Grand Masters of the Art World, both present and past.

When the institutions that act as focal points for Art education have not been established other methods and techniques are developed by individuals and organizations to fill the voids where Museums and Galleries might otherwise be. Art education is fluid; therefore, when one avenue to learning in not available, other approaches to the learning and development of the field are realised. As Shaw (1997: 169) supposed that Oman is a prime example of a country that has developed alternative sources of learning and collaboration to help develop art education. Most of the services and activities provided to the Omani communities are planned and carried out through the University's co-operative efforts with the various ministries and local institutions. Collaboration has played a key role in Oman's development of Fine Art education. Foreign artists come to Oman to join local artist in order to work together in collaboration at local art institutions such as the Youth Art Studio, The Cultural Club, The Fine Art Group at Sultan Qaboos University, The Art Education Department at SQU and the Omani Society of Fine Art. These Arts institutions hold annual art exhibitions. They contribute to create a new generation of Omani artists. Also, Artists from Oman are taking it upon themselves to travel abroad to find new influences and gain more knowledge that would otherwise not be available locally. These meetings help to inspire creativity and give the opportunity to artists to explore and exchange their knowledge of contemporary Art (Al-Yahyai, 2013).

In order to improve the quality of teaching Art Education in Oman, Al-Amri et al. (2016) argue that schools and art education need to establish stronger links, cooperation and partnerships with art museums, galleries and exhibitions if they want to improve the quality of teaching Art Education as an academic discipline among school curriculum. In fact, this kind of cooperation and partnerships can offer an important source of Aesthetics, Art Criticism, Art History, Art Production, Cultural Inquiry and world-wide multiculturalism arts.

Collaboration also helps awareness of cultural and social issues that might affect wider artistic creativity. Collaborative projects help to develop open-minded approaches to the furthering of the Fine Art movement in general and provide a supportive and creative atmosphere were social and cultural development and understanding take place. Access to the cultural experiences of others promote an appreciation of their humanity, even when the details of their culture are radically different from their own. This practice and exposure fosters not only a 
deeper understanding of what Fine Art is but also an appreciation of the culture that created it and therefore gives access to the inner experience of that culture and its Fine Art.

One of the most important factors in the development and education of the Fine Art movement in Oman is the country's ability to retain knowledge within the country. As many countries suffer from "brain-drain" due to the most knowledgeable and experienced individuals leaving their home nations, Oman has managed to keep hold of those whose expertise in Fine Art is invaluable and can be shared with others. Al-Yahyai (2013) supported that by saying "The returning Master's and PhD degree holders in Fine Arts Education to the country [...] play a role in creating a new generation who have a responsibility for developing the art movement in terms of knowledge and quality in making and appreciating artwork, as well as developing the art criticism movement in Oman" (Al-Yahyai, 2013: 4-5).

\section{The Potential Effects of Museums on Omani Art Education}

According to Al-Amri et al. (2016) Art museums and galleries offer many fascinating collections to be looked at, drawn, written about and handled. Theses museums and galleries are the good places to achieve the most important goals, aims and objectives of the quality art education. Therefore, the importance of a complete and fully rounded understanding of Art cannot be understated when discussing the development of Artists and Art Teachers. A critical understanding of Art, including practical, historical and aesthetic comprehension are vital to the development of Artists and their work, this can be called the language of Art. This language provides a complete education and allows individuals to progress their own theories and practices as well as being able to share their understanding with others. In turn an understanding of all areas of Art will improve the quality of Art Education. It is necessary, therefore, to build Art students' knowledge not just on a practical basis in classrooms but, importantly, developing their understanding and appreciation of the theoretical, aesthetic and historical contexts in which Art lies. As mentioned earlier, Museums play a fundamental role in the classroom development of the language of Art, which underpins the very foundations of the Artists' creative understanding and development.

The progress of Art in Oman is dependent on Artists' understanding of the language of Art. Therefore, Omani Art education needs to reflect the importance of this development through Curricula designed to encompass the range of disciplines necessary for Art students' to achieve advanced comprehension in the language of Art. Using the Discipline-Based Art Education (DBAE) theory, which uses a balanced approach to Art education, in terms of aesthetic and critical development, and also uses a range of contexts to include Eastern Arabian and European Art, a study was conducted at Sultan Qaboos University (SQU) to assess the standards of the students' development of their understanding in the language of Art. As explained by Al-Amri (2010).

The results show that the lecturers at SQU do not focus highly on the Art 
content, which is derived from the four disciplines [Art History, Art Criticism, Aesthetics, and Art Production]. On the contrary, the main focus was on the discipline of Art Production, suggesting an Art-Studio orientation. However, the standard in this discipline, Art Production, was not rated very highly by the students or the researcher (Al-Amri, 2010: 1).

The results of the research confirm the importance for Art education to include all areas of the Art language for students to be able progress fully. Without this progress, Omani Art students' growth and understanding will be incomplete and they will struggle to develop and share their knowledge and practical abilities in the future. Al-Amri (2010) goes further in his analysis of this research's results by saying: "The results also suggest that the Art Education department at SQU should adopt a clear philosophy of teaching and learning in and through Art and that the Art content for the Art bases course should derived from the four disciplines as well as from related fields such as Multiculturalism, New Technology, Educational Museum” (Al-Amri, 2010: 7).

Al-Amri's (2010) comments suggest the need for Art courses to be designed to help Art students develop a breadth of knowledge in Art. This confirms the principle that Art Education needs to happen not only in classrooms but also outside to help students' understand aesthetic and be able to criticize Art constructively. Museums are the key to this development. Museums are the cornerstone in the development in an individual's comprehension in the language of Art. Furthermore, (McMahon, Klopper, \& Power, 2014) rich a fundamental conclusion suggesting that the researches and studies in art education expressed views proposes an agreement that for young learners, engagement in the arts enhanced their social, emotional and academic outcomes, as well as their knowledge and understanding which are important for investment in humanities.

\section{Conclusion}

As a conclusion, it could be said that art teachers who are trained to utilize $\mathrm{Mu}$ seums' resource are more likely to include it in their instructional methods for teaching Art Education in their classrooms. As a result of this utilization, students' vocabulary and knowledge are becoming significantly enhanced by these reliable sources. Generally, museum is a place of sanctuary removed from the outside world. Sir Kenneth Clark, the former director of the National Gallery in London, in (Prezios, 1998: 479) explains that "The only reason for bringing together works of art in a public place is that... they produce in us a kind of exalted happiness. For a moment there is a clearing in the jungle; we pass on refreshed, with our capacity for life increased and some memory of the sky."

Furthermore, Museums now enable the public to explore collections for inspiration and learning. In the last few decades, museums have grown exponentially in number, size and variety, and now people go to museums more than ever before. Free admissions days and discounts are available. People from different backgrounds and all ranges of income visit museums. Gurian (2006: 142) explains that a museum visit is often an opportunity for parents to teach their 
children, but also for children to demonstrate knowledge their parents didn't know they had. Art and cultural institutions have both qualitative and quantitative effects on students, especially when those students are reliant on their schools to provide culturally enriching experiences.

They are a resource not only for students and casual learners but also an educational tool for working professionals. Nowadays, many museums offer "artist in Residence" programs and open studios where the public and professionals can get inspired and gain an insight into artists' creative works. Museums are places where the visitors can meet artists, designers, and scientists and find out more about education and career pathways and even host job-training programs.

Finally, Art Museums provide students, teachers and professional Artists with an unparalleled resource to develop knowledge and understanding on practical, theoretical and aesthetic levels. Oman would see quantifiable increase in the standards of Art Education should access to Fine Art museums and galleries be freely available. Students' abilities to understand Fine Art in its entirety would be backed by a teaching resource far greater than monotonous and unwavering dedication to classroom-only teaching. Teachers would be able to offer their students experiences and knowledge which would otherwise be impossible to explain or replicate in a classroom environment. In turn, the benefits would be evident in the quality of Artists and Art teachers in the country, who would, in time, be recognized by their peers internationally. It is therefore of the upmost importance for Oman to proceed with the development of Fine Art centers if the country wishes to continue to progress in the world of Visual and Fine Art.

\section{Acknowledgements}

There is no funding to declare for this article.

\section{References}

Al-Amri, M. (2001). Living Heritage: The Influence of Oman Heritage in Omani Contemporary Art. Mirat Al J’ama (pp. 28-33). Muscat: Sultan Qaboos University Printing Press

Al-Amri, M. (2006). Art and Craft Education and Its Institutions in Oman. Conference Paper for the 1st World Conference on Arts Education, UNESCO, Lisbon, 6-9 March 2006.

http://www.academia.edu/4235458/Al-Amri_M._2006_._Art_and_Craft_Education_an d_Its_Institutions_in_Oman._Conference_paper_for_The_1st_World_Conference_on Arts_Education._UNESCO._Lisbon_6-9_March_2006

Al-Amri, M. (2010). Evaluating Art Studio Courses at Sultan Qaboos University in Light of the Discipline Based Art Education Theory. Journal of Instructional Pedagogies, (USA), 2, 103-123.

Al-Amri, M., Al-Radaideh, B., Al-Yahyai, F., Almamari, B., \& Alhajri, S. (2016). Artists and Their Artworks as a Model for Improving the Quality of Teaching in Art Education. British Journal of Arts and Social Sciences, 21, 59-71.

Al-Yahyai, F. (2013). The History of Omani Women in the Fine Arts Movement. The International Journal of Arts and Theory and History, 7, 1-20. https://doi.org/10.18848/2326-9952/CGP/v07i01/36240 
Anderson, J. (1991). A Living History Reader: Museums. New York: SAGE Publications Inc.

Cook, B. A. (2007). A Chronological Study of Experiential Education in the American History Museum. Ph.D. Thesis, Texas: University of north Texas.

Dewey, J. (1913/1970). Interest and Effort in Education. New York: Augustus M. Kelley.

Dewey, J. (1933). The Later Works, 1925-1953. In J.A. Boydston, B. A. Walsh \& H. F. Simon (Eds.), Collected Works of John Dewey. Carbondale, IL: Southern Illinois University Press.

Gibson, R. (2003). Learning to Be an Art Educator: Student Teachers' Attitudes to Art and Art Education. International Journal of Art \& Design Education, 22, 111-120. https://doi.org/10.1111/1468-5949.00344

Gurian, E. H. (2006). Civilizing the Museum: The Collected Writings of Elaine Heumann Gurian. Now York: Routledge.

Hein, G. (1998). Learning in the Museum. (Museum Meanings). New York: Rutledge.

Holtrop, E. (2016). Research Initiative: Impact of Art Museum Programs on K-12 Students White Paper. Seattle, WA: National Art Education Association (NAEA), the Museum Education Division of NAEA.

https://www.arteducators.org/community/articles/79-museum-education-division

Hooper-Greenhill, E. (2007). Museums and Education: Purpose, Pedagogy, Performance (Museum Meanings). New York: Routledge.

Innis, E. R. (2008) Susanne Langer in Focus: The Symbolic Mind. Bloomington: Indiana University Press.

International Council of Museums (2007) Museum Definition, The world Museum Community. http://icom.museum/the-vision/museum-definition/

Langer, S. (1967). Mind: An Essay on Human Feeling. Baltimore, MD: The Johns Hopkins University Press.

Marstine, J. (2006). New Museum Theory and Practice: An Introduction. Oxford: Blackwell Publishing. https://doi.org/10.1002/9780470776230

McClellan, A. (2003). Art and Its Publics: Museum Studies at the Millennium. Oxford: Blackwell Publishing. https://doi.org/10.1002/9780470775936

McMahon, A., Klopper, C., \& Power, B. (2014). Excellence in arts Based Education-One School's Story. International Journal of Education \& the Arts, 15, 5.

National Art Association (2017) Why Art Education? http://www.arteducators.org/advocacy/why-art-education

Prezios, D. (1998). The Art of Art History: A Critical Anthology. Oxford: Oxford University Press.

Shaw, K. E. (1997). Higher Education in the Gulf: Problems and Prospects. Exeter: University of Exeter Press.

Stone, D. L. (1996). Preservice Art Education and Learning in Art Museums. The Journal of Aesthetic Education, 30, 83-96.

https://doi.org/10.2307/3333323 
Submit or recommend next manuscript to SCIRP and we will provide best service for you:

Accepting pre-submission inquiries through Email, Facebook, LinkedIn, Twitter, etc. A wide selection of journals (inclusive of 9 subjects, more than 200 journals)

Providing 24-hour high-quality service

User-friendly online submission system

Fair and swift peer-review system

Efficient typesetting and proofreading procedure

Display of the result of downloads and visits, as well as the number of cited articles Maximum dissemination of your research work

Submit your manuscript at: http://papersubmission.scirp.org/

Or contact adr@scirp.org 